\title{
2. When the barking stopped: Censorship, self-censorship and spin in Fiji
}

\section{COMMIDNHARY}

After four military coups in 20 years, Fiji is poised to return to democracy in elections promised for 2014. An emergency decree placing censors in newsrooms was lifted in January 2012, but with domestic media gagged by lawsuits and Fiji Television threatened with closure for covering opposition figures, a pervasive climate of self-censorship imposed by government decrees is enforced by a government-appointed judiciary. As elections draw closer, the illusion of press freedom is framed by highly-paid American 'spin doctors' from a prominent Washington DC public relations and lobbying firm. Paralysis in the newsroom is reflected at Fiji's premier University of the South Pacific. The author taught television journalism at the university and trained reporters for Fiji TV in the 1990s, but returned to find Fiji's media and higher education in a crisis. Student grievances over harassment and expulsion in retaliation for independent reporting echo the deceit and dysfunction unfolding on the national stage. As traditional allies Australia, New Zealand, United Kingdom and the United States anguish over sanctions, unprecedented visits to Fiji by Russian Foreign Minister Sergei Lavrov and Chinese President Xi Jinping portend diplomatic rivalry and raise the stakes for this Pacific nation.

Keywords: censorship, diplomacy, journalism education, self-censorship, television training

ROBERT A. HOOPER

University of California, San Diego

Censorship reflects society's lack of confidence in itself. It is a hallmark of an authoritarian regime.

- US Supreme Court Justice Potter Stewart 
I

N THE Pacific Islands, I am often asked, 'How does journalism serve our people when we face more urgent problems like poverty, corruption, failed economic development, climate change and disease?' I respond with a question, 'When you visit your cousin's village unannounced, what is the first thing you hear?' Pause. 'Barking dogs!' is the unanimous response from Fiji to Guam. 'They warn us if a stranger is coming. Maybe your cousin, maybe a thief.'

In 2009, after four coups and yet another government run by military officers and their toadies, Fiji's barking dogs of the once-free press went silent. The government deported top journalists or took them to the Queen Elizabeth army barracks where they were threatened or abused. Many journalists emigrated or left journalism altogether. The government compelled Fiji TV to remove its proficient news director at the insistence of an army officer who served on its corporate board. The government's pressure gutted the venerable Fiji Times and forced the departure of its publisher and editors.

When I returned to Fiji the following year it was the silence that struck me. 'Yes, broken like a broken watch,' Gabriel Marcel once wrote when Hitler came to power in Berlin. 'The mainspring has stopped working. Just look at it; nothing has changed. Everything is in place. But put the watch to your ear, and you don't hear any ticking (Marcel, 1933/1998, p. 47).

I walked the busy streets of Suva, Fiji's capital. The once charming city, a financial, educational and journalistic heart of the South Pacific, was rife with rumour, propaganda and paranoia. The once courageous Fiji Sun praised government in bloated headlines posing as news. The third daily newspaper, Fiji Daily Post, was gone. The Fiji Times, a bellwether of Fiji journalism since 1869, emphasised weather and sports. I tuned into Fiji Television that evening for the news, having trained their reporters 15 years earlier. The newscast featured better lighting, better graphics, better reporting and weaker stories - or non-stories posing as news - like coverage of yet another dreary conference hosted by a UN agency or international charity. I had returned to teach 'independent and free media' - in the provocative language of my grant - in a nation that permitted neither.

I first came to Fiji in 1993 to lecture and help develop a TV journalism course at the University of the South Pacific, a regional university based in Suva (Hooper, 1998). I departed late the following year at a time of high expectations. A new constitution that guaranteed 'freedom of the press and 
other media' was being drafted with input from Fiji's ethnic and political elites, journalists were free to report with few limitations, and a lively press corps met weekly to share stories over cold beer hosted by the venerable former Lord Mayor of Suva, Sir Leonard Usher. Former Prime Minister Sitiveni Rabuka, an army officer who had staged the first two military coups in 1987, informed my students - live, on camera - that Fiji's only future lay in democracy and press freedom.

When Fiji, after 96 years as a British Crown Colony, gained its independence in 1970, England left behind a well-equipped and fully-armed standing army, an accident waiting to happen. Like dominos falling, an aborted third coup in 2000 led to a fourth coup in 2006. When Fiji's Court of Appeals ruled both the 2006 coup and the self-appointed government of Commodore Josaia Voreqe 'Frank' Bainimarama illegal, Fiji's President Josefa Iloilo sacked the judiciary of Fiji and abrogated the 1997 Constitution. By the time I returned in 2010, Fiji's courts were packed with temporary ‘judges' hired from Sri Lanka and other Commonwealth nations. When judges are not elected by the people nor appointed by their elected representatives, the result is not a judiciary but a theatre of the absurd. When The Fiji Times quoted a football secretary on its sports page who questioned the legitimacy of Fiji's judiciary, both the secretary and The Fiji Times were convicted of 'contempt of court' on 1 October 2012 (Swami, 2012). As Franz Kafka reminds us in The Trial, '...it is an essential part of the justice dispensed here that you should be condemned not only in innocence but also in ignorance (Kafka, 1925/1998, p. 55).

While the United States appears caught off-guard by Pacific events of recent years, one must recall that the 1990s were a time of global drawdown by America and its allies and Fiji appeared to pose little military or diplomatic threat. The Chinese Embassy was housed in a small office building in Suva and someone joked that they also did take-out. More seriously, the accepted wisdom was that Australia and New Zealand were in charge and the United States could safely withdraw under the impression that everything was under control. Reluctantly, I moved on to other parts of the world, but returned in 2010 for a two-year project teaching investigative broadcast journalism at Fiji TV and the University of the South Pacific.

My first job was to restore investigative television journalism skills for Fiji TV news reporters deeply scarred by recent events. Under such circumstances, it is essential that the skills and pedagogy of world-class 


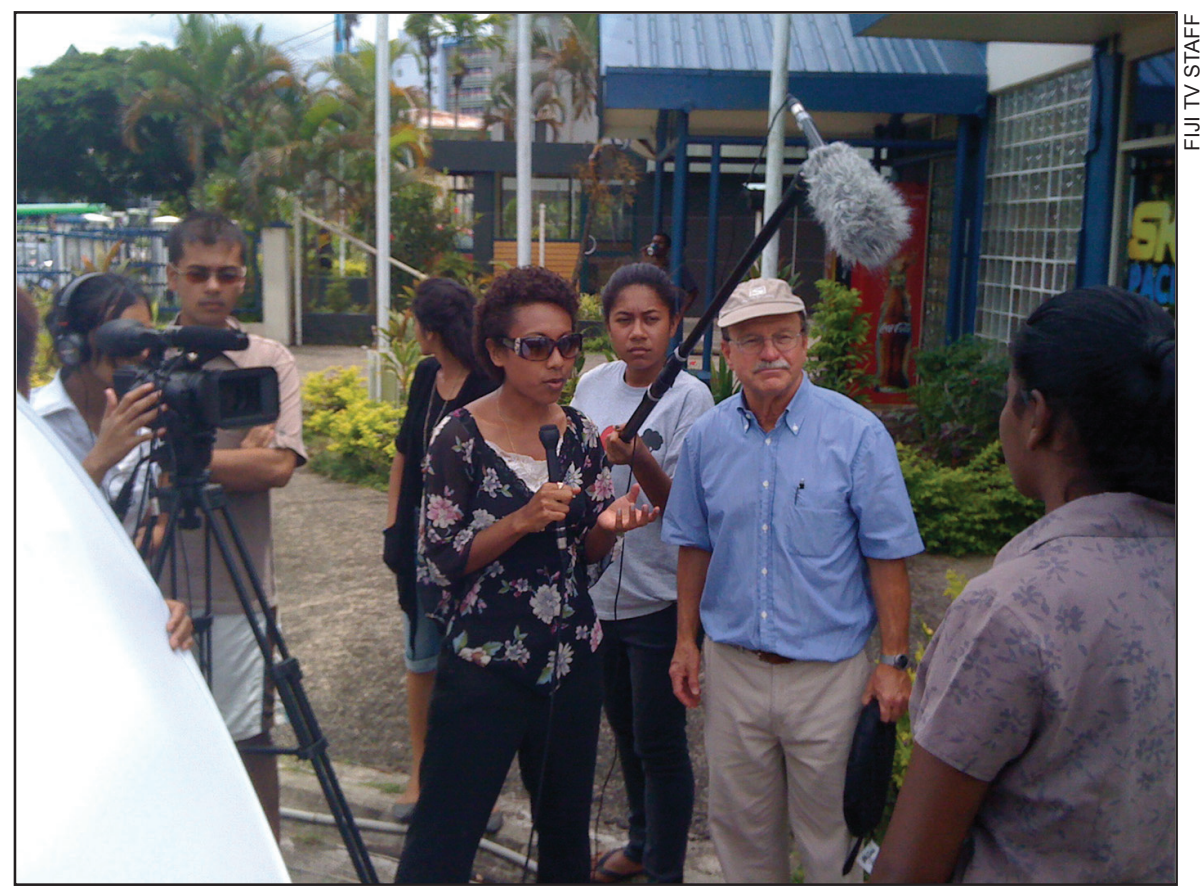

An investigative journalism workshop for University of South Pacific students conducted at Fiji Television, August 2010.

journalism be preserved even if their practice is not presently allowed. I stressed the coverage of controversial stories on issues of national importance that, if produced, would be banned under Fiji's Public Emergency Regulations (PER) - an edict issued in April 2009 that placed censors in newsrooms - and the Media Industry Development Decree of June 2010, a vaguely- worded law that criminalises anything government deems is 'against the public interest or order'. Under PER, overt censorship as well as self-censorship became routine at Fiji TV in 2009, in stark contrast to the openness and independence of the newly launched Fiji TV whose reporters I trained in the 1990s. Until PER was lifted in January 2012, military censors arrived at Fiji TV's newsroom daily at $2 \mathrm{pm}$ and $5 \mathrm{pm}$ to suppress stories deemed 'political' or 'critical of government'. The arrest of reporters and confiscation of videotapes led swiftly to self-censorship in a demoralised newsroom.

Paradoxically, journalists felt safer when government censors determined what would be banned or permitted to air. Without PER, any story might 
land a reporter in jail for offences under a Media Decree subject to arbitrary interpretation by government officials. Even after PER was lifted, Fiji TV journalists continued to practise excessive self-censorship, and intimidation in the newsroom was palpable. Accordingly, I deliberately encouraged stories that would not be permitted to air to preserve a culture of media freedom and open access to information from multiple sources that existed in Fiji prior to 2009. Each class participant had complete freedom to develop a story and script on any topic or issue of interest. When the watch stops, you do what you can to protect the watchmaker. If they kill the watchmaker, Fiji risks joining a lengthening list of 'troubled countries' almost impossible to restore.

An example of just how far censorship has reached into the newsroom is an interview by a senior reporter with a Fiji schoolteacher. Using techniques introduced in class, the reporter probed the issues, challenges and problems faced by primary and secondary schoolteachers and effectively elicited informed and articulate answers about student misbehaviour, overcrowded schools, poor classroom conditions and the failure of government to deliver on promises to fund improvements in several school districts. Without seeking input from teachers or the public, Fiji's Education Minister, Filipe Bole, announced in June 2010 that national external examinations for Fiji's students would be scrapped the following year. The schoolteacher was worried.

It was an extraordinary interview and I suggested it could be edited for a feature news story or included in a longer format programme for the station's Close Up newsmagazine series. But the teacher said she would be fired from her teaching position and the reporter would be questioned and disciplined (not to mention, censored) if we attempted to broadcast it. This is how extreme the situation has become. When Fiji faces a crisis in failing schools and rising illiteracy in future years it will be traced back to missed opportunities like this to inform Fiji's citizens and encourage reform.

On 10 September 2010, I accompanied a Fiji TV reporter to a government presentation held at Parliament House (closed and shuttered following the coup in 2006) on the topic: 'Political Landscape and Development Blueprint for Fiji'. Lists of 'Outputs' and 'Outcomes' by each government ministry were displayed as coloured dots to reveal progress or the lack of it. Evidence of 'progress' was revealed in photos tacked to the opposite wall, according to a government representative. At my suggestion, the reporter asked him for an interview, which he agreed to, to discuss the criteria used to measure 
progress in specific 'outcomes' such as education. Fiji TV set up a camera in front of Parliament but when the spokesperson emerged and saw the camera he abruptly walked off without a word. The very notion of a press conference or response by government was clearly out of the question.

At $5.30 \mathrm{pm}$ we were back in the newsroom feverishly editing the story for the $6 \mathrm{pm}$ newscast when a government censor walked in and demanded scripts for the day's news segments. He retired to the staff tearoom to select ones for censoring. Ironically, he selected 'Political Landscape and Development Blueprint for Fiji'. I asked him what he could possibly find in a story about a government presentation that would 'threaten public order'. He didn't laugh. He removed a few lines and walked out.

Where the lines are drawn is subject to interpretation: a newscast on prostitution was restricted to coverage of local women, ignoring the influx of foreign sex workers without work permits or visas to reside in Fiji. For a segment on foreign prostitutes, reporters must obtain written clearances from the ministries of Immigration and Labour, which routinely fail to respond, thereby effectively censoring stories through indirect intimidation and lack of official recognition.

A follow-up story on human trafficking of children was effectively killed because repeated requests to the Education Ministry went unanswered. Yet another story produced in my class on expired leases for agricultural lands and the success story of one evicted family from Vanua Levu that returned to its farm was not broadcast. The reporter could not get clearance from Fiji's Native (iTaukei) Land Trust Board, even after he interviewed its representative.

Numerous events tightened a net of fear and paranoia among Suva journalists. My former USP teaching assistant was arrested and convicted under PER. When he sought my assistance in seeking asylum, I met with US Embassy officials who warned me to be careful, that he was probably being tailed. An American journalist had just been caught in a surveillance sting at the local internet café and swiftly deported. My old pals in the Australian press corps had all been deported, many for the second time. Fiji's journalists did not meet over cold beer anymore, Sir Leonard Usher was dead, the Fiji Islands Media Association (FIMA) disbanded; it was all very depressing. My former teaching assistant now lives in California.

In today's interconnected world, when a nation's journalists are bound and gagged, freedom of the press is outsourced to blogs and websites hosted 
on offshore servers. Without corroboration, fact checking or editorial supervision, truth becomes elusive in a cacophony of rumor, opinion and spin. In Fiji, white expatriates, including those born in Fiji under colonial rule who pretend to be 'native', delight in shouting down the real natives on blogs that claim censorship ended when PER was removed, self-censorship does not exist, the forced sale of The Fiji Times by government decree was for the good of Fiji and the truth is what they say it is - if you know what's good for you! It is only the most recent version of a neocolonialism Fijians know intimately.

To teach world class broadcast journalism under adverse circumstances requires living in two worlds: preparing reporters for a democratic future of information transparency and press freedom while helping them adapt and survive in the present. In Fiji, reporters must now submit itemised questions before an interview with a government official; additional questions or 'deviations' are not permitted. This contradicts techniques I teach for effective TV interviewing - I encourage 'deviations' in response to the issues raised - but it is a reality faced by journalists today. One Fiji TV reporter had his videotapes confiscated because the government minister he interviewed did not like his 'tone of voice'. The minister cited Fiji's Media Decree without explanation or appeal. Journalists develop a keen sense of discrimination, erring on the side of censorship when coverage might trigger a reaction from government. A persistent risk in building capacity in Fiji's media for the future is blowback in the present.

A standard technique for reporting political controversy in the United States is to cover both sides of an issue fairly and with equal emphasis. If a government figure makes a charge against an opposition party or politician, equal time and opportunity must be provided for an effective response. Not the case in Fiji. When Taufa Vakatale, Fiji's first female Deputy Prime Minister and a government-appointed member of the Constitution Commission, accused democratically-elected politicians from the past for Fiji's 'current state', Fiji TV reporters interviewed two deposed former Prime Ministers, Laisenia Qarase and Mahendra Chaudhry, for response. Within days, Fiji's Attorney-General Aiyaz Sayed-Khaiyum threatened Fiji TV management with loss of its broadcasting licence. To drive home the threat, a new Television Amendment Decree \#52 was issued in June 2012 enabling the Ministry of Justice to revoke a television broadcasting licence for alleged breach of media 'ethics and practices', without opportunity to appeal. At the end of June 2012, 
Fiji TV's 12-year licence was not renewed for the first time in history. In the final hours, a licence 'extension' for six months served as a direct warning not to cover opposition figures. The Attorney-General is rumoured to keep a long list of former democratically-elected politicians whose interview would violate 'ethics and practices'.

An on-camera TV interviewing exercise revealed the consequences of suspending press freedoms and jailing reporters for doing their jobs. A senior reporter discussed his arrest and detention for covering the abrogation of Fiji's constitution and the dismissal of appeals court judges who ruled the military government illegal. The military government charged him with violation of PER and took him up to the Queen Elizabeth Barracks for a rough interrogation. The following interview was conducted by senior reporters at Fiji TV under my supervision, but never broadcast (Fiji TV Newsroom, 2010):

INTERVIEWER: How did you come to be arrested?

JOURNALIST: It was my first time being arrested. An Australian reporter gets deported, we get wind of it, we rush over to him, we have the interview, we get the shots, we have him being bundled into a car and driven off. Unfortunately, we didn't get to air it, they came, they censored it, it was blocked.

How does that make you feel; are stories out there you want to cover? It kills your spirit. There is so much going on now in the country that people don't even know about.

What is the story that most touched you?

This five-year-old boy who had a broken arm. His parents went to hospital and he never went home. Yesterday, the parents were still asking for justice.

So will you be taking up the story anytime soon?

I'd like to but it's most likely going to be censored.

Even stories like that?

Anything and everything. There's no formula for censorship. It's on their whim...

So media has no power over what people want us to inform them?

Media was never in a position of power. Right now we're restricted in how much information and what information we can give our viewers. So people don't know what's going on in the country - they get a very rosy picture of what certain people in power are doing.

So how are we going to return to democracy if we never inform the people? 
Good question.

What will be the impact on media if you're not allowed to cover those stories?

Two years ago I was very proud of what I do. I went out there, I got the big stories, I got into people's faces, I asked the hard questions, I chased around ministers and all these people in power and I loved doing it because I knew I was making them accountable. Right now I can't do that. I can't ask any hard questions. I can't bring up issues of relevance. I can't poke or prod or investigate.

This interview haunts me. The reporter questioned why anyone with talent or experience would want to become a journalist in Fiji. He fears Fiji will lose an entire generation of experienced reporters and editors. Without top senior journalists to mentor the young ones, to rebuild Fiji's press corps is left in the hands of media academics at the University of the South Pacific (USP), the leading regional programme, and Fiji National University (FNU), a reorganised local institution that launched a media and journalism programme in 2003.

After 16 years away from Fiji, my heart sank when I returned to USP and found the Journalism Programme in disarray. Founded by François Turmel, a former editor for the British Broadcasting Corporation (BBC), and implemented in February 1993 with a grant from the French government, it overcame numerous obstacles and bitter opposition by local figures to produce 81 degree and diploma graduates by 2004. Earlier programmes had failed. It was initially housed in the USP Media Centre with professional TV studios and editing suites, a lively campus radio station, and a professional engineering and maintenance staff to keep it running like a Swiss watch. Many of today's outstanding reporters and senior journalists were educated during this period and a successful news website, Pacific Journalism Online (www.usp.ac.fj/ journ/) was launched by journalism coordinator David Robie in 1998 and provided award-winning coverage of the 2000 coup (Robie, 2004). ${ }^{1}$ Following Robie's departure in 2002, Mumbai journalist Dev Nadkarni and a former Fiji editor (The Review), Shailendra Singh, continued to build the programme as political headwinds finally reached boiling point with Fiji's fourth military coup in 2006. This political crisis precipitated a leadership crisis in higher education in Fiji that continues to this day.

In April 2008, the Media Centre was abruptly closed and its engineer- 


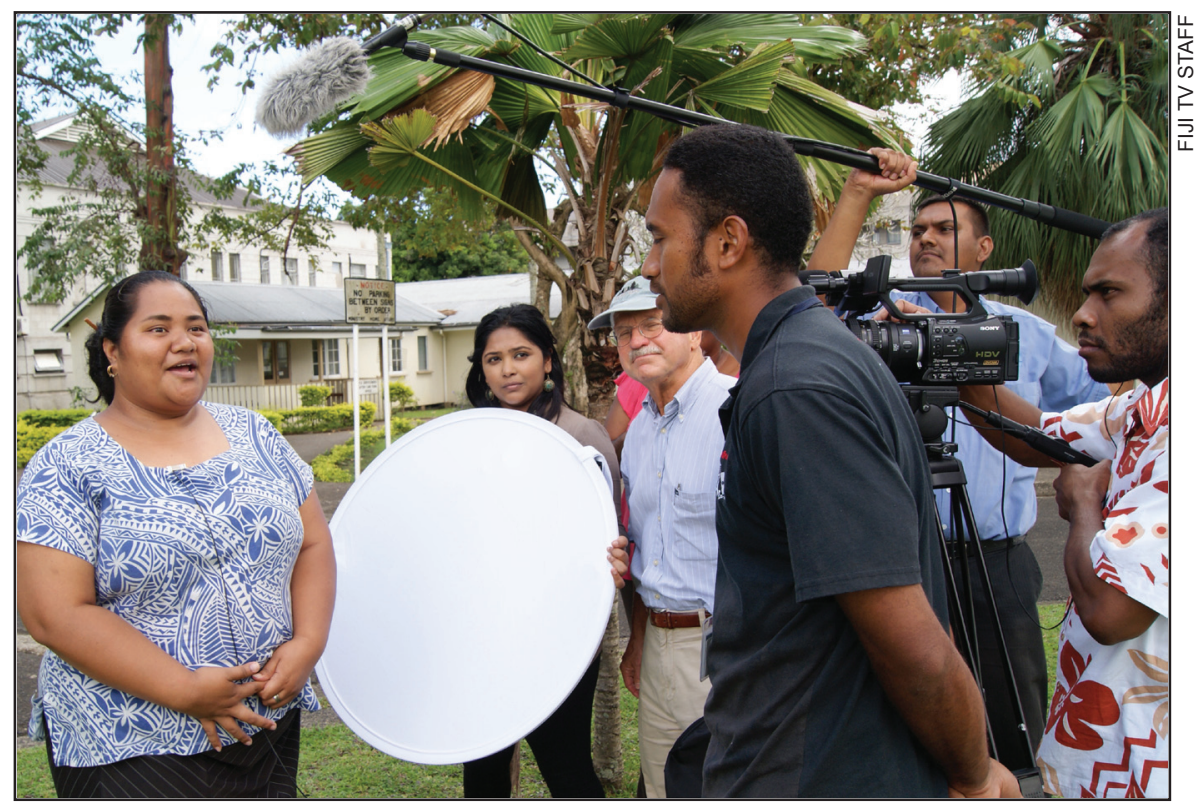

An interviewing workshop for Fiji Television journalists and staff.

ing staff dismissed just over a year following the 2006 coup. A protest strike by 400 USP staff was decreed illegal (Delaivoni, 2008). Campus radio went silent. Some blamed it on poor management at USP, others on budget deficits. When I returned in 2010, the Media Centre housed a Law School and stateof-art television studios had been converted to storage rooms. It was clearly impossible to teach broadcast journalism under such conditions.

I could think of only one alternative: teach TV journalism courses at Fiji TV in partnership with USP. This collaboration would strengthen both journalism education and professional broadcasting by educating future reporters, producers, news editors and programmers in a professional environment. To my surprise, both Fiji TV group chief executive Tarun Patel and USP vicechancellor Professor Rajesh Chandra readily agreed.

Over the following year, I taught basic TV journalism followed by investigative TV journalism. Fiji TV reporters worked side by side with USP students to produce extraordinary news stories under challenging circumstances. Under a pedagogy pioneered by the University of California, Los Angeles (UCLA), students were given complete freedom to develop stories on any 
issue, regardless of the political repercussions under the PER or Media Decree. Fiji TV generously hosted the courses in spite of heavy work schedules and equipment shortages in their newsroom and received no financial compensation. The university posed obstacles.

One day in 2011 the USP teaching assistant disappeared with the university's TV cameras to work on paid projects, leaving students without equipment or technical assistance. In response, Fiji TV shared cameras and staff to help students even when short on both. The university's editing room was only open weekday hours when students were busy with classes. Fiji TV opened its editing rooms to students at all hours, seven days a week. In the end, every student completed a final project. Several were outstanding.

The top award went to Bangladesh's Supermum, the tragic story of a young widow and her children forced into poverty (Sharma, 2010), but no awards went to Recycle, a searing investigation into duplicity and deceit at the USP recycling programme. A USP Maintenance Department employee confirms oncamera that plastics and glass are mixed with rubbish as video images reveal his truck dumping recyclables into the rubbish bin. 'What we collect, at the end of the day, has to go into the landfill,' asserts Naresh Narain, senior health inspector for Suva City Council. Interviews with USP staff and faculty reveal the hypocrisy of this practice - in contrast to the sustainable environmental practices promoted by the university. It was the best investigative journalism completed by any student but it was in vain. Its implied culpability of officials ensured its rejection.

Recycle was omitted from the final student screenings and not nominated for an award. In a pervasive climate of censorship and suppression of press freedom, even investigative journalism that uncovers significant issues at a local university can be viewed as controversial. Such incidents at USP reflect the deteriorating circumstances of its host nation and a pervasive climate of retaliation and paranoia. The recent resignation of USP tenured economics academic, Professor Warden Narsey, who published an article on Fiji's finances that embarrassed the government, cast a pall on the entire faculty. The clumsy suppression of Recycle fits that pattern.

The student who produced Recycle thought she had failed, but returned to class at my insistence to produce another searing television report on a young boy working the streets of Suva to support his mentally-ill mother. She accomplished this in spite of an academic programme that almost ruined her 
life. But her success and the sustainability of television journalism education in the Pacific are at risk.

For the advanced course in 2012 students chose ambitious investigative news stories involving corruption at the Fiji National Provident Fund (FNPF), internet gaming addiction and school dropouts, child poverty, Pacific media freedom and the impacts of arbitrary government decrees. One student interviewed Superintendent of Police's Legal Director Sivoki Tuwaqa about a new Crimes Decree 333, Subsection 1, the so-called 'Gossiping Law'.

The student journalist confronts Officer Tuwaqa: 'What if a person thinks something is true, but it turns out to be false? Is he still liable?' Officer Tuwaqa: 'Anybody who spreads any information they cannot prove is "correct" is in violation. You have to prove it to me, to the court. [He stammers]. The burden of proof is on your side!'

Student journalist: 'Have any arrests been made under this law?'

Officer Tuwaqa: 'No arrests have been made so my work is to advise them that they can be prosecuted. It's one year in prison, so it is very serious.'

The student proudly concludes: 'USP Journalism has finally confirmed that gossiping is against the law.'

The following week in class as students investigated stories, discussed ideas and wrote scripts, I was asked by USP staff to assign the topic 'Pacific Media Freedom' to all students for a conference planned in September 2012. In response, I patiently explained the pedagogy of encouraging students to choose their own topics and how it enabled the production of extraordinary TV stories the previous year. In the absence of a response, I reminded students they had complete freedom to choose a topic. One student chose ' $\mathrm{Pa}$ cific Media Freedom' because her government asked her to attend the Pacific Islands News Association (PINA) conference scheduled for Fiji at the end of March. Other students were 'assigned' to a TV crew to videotape the conference and simply disappeared from class during a critical week of TV field production.

In spite of power outages, massive flooding, equipment shortages and the PINA conference, students once again completed their final projects on time - except one. The student who chose Pacific Media Freedom confronted a crisis when she insisted on editing her own story and reported: 'A lot of people 
want to give their opinions about it... but as you might also have heard, there is a HUGE drama in our school about that topic... All the interviews that I've done at (the Pacific Media Summit) were not under my control!!! I thought that it was just OUR ASSIGNMENT for JN 305 class... it was hard to deal with the pressure at school about THAT particular topic... since I lost the control of the documentary...' (Hooper, 2012). Unfortunately, she was caught up in a project devised and controlled by the USP faculty to produce a documentary funded by the International Federation of Journalists' Asia-Pacific office in Sydney. To educate students by encouraging editorial control of their work was not the goal.

Eventually, the student was removed from her project over the issue of editorial control and two classmates completed a faculty-approved version. It was unfocused and weak. The student persevered and recovered her tapes. She edited her own version that featured skilled professional interviews with Fiji Times editor-in-chief Fred Wesley and Pacific Media Centre director Professor David Robie - both omitted from the faculty-approved version. It was excellent and received a top grade. But the student received failing grades from other faculties and was expelled from the Journalism Programme without an opportunity to appeal. She concludes, 'I was just always in my right to share my opinion. Well I thought so. We do not agree regarding the sensitive topic of "freedom of the press" in the Pacific. He [her supervising lecturer] is victimising me because of different views about the PINA summit.' Despite superior work and class performance, this student has returned to her home country without her degree in journalism.

Lost in the drama and confusion was the 2012 Pacific Islands News Association (PINA) Media Summit. Originally scheduled for Papua New Guinea, PINA moved the summit to Fiji, provoking controversy in a media organisation professing press freedom in a nation that possessed none. I accompanied Fiji TV staff to cover the opening address by Fiji's Prime Minister, Commodore Voreqe Bainimarama.

The commodore arrived late. Reading off a script verbatim, he stumbled over his words praising Fiji's journalists and asked us to consider Singapore as a role model for Fiji. In the past, he had cited China and I wondered if it signaled a policy shift. Back at the hotel, a fellow American beckoned me over to his table to share a fine bottle of wine. He worked for Qorvis Communications, a large Washington, DC public relations firm hired by Fiji's 
government 'to modernise how it communicates it messages'. He told me Frank (Prime Minister Bainimarama) was late to the PINA Summit because of last minute revisions he (the American) had to make to Frank's talk. He argued that to make political progress in Fiji he must help the Bainimarama regime change 'how it communicates its messages'. It was all outlined on a website back in Washington.

I asked how such spin could lead to political change when journalists are punished for covering opposition figures or questioning the legitimacy of Fiji's judiciary after the constitution was abrogated. 'They know it's not sustainable,' he sighed. 'Six people are running the entire government.' I interpreted this to mean that elections promised for 2014 will take place. But will they be free and fair? Will Fiji's Attorney-General pull Fiji TV's licence to silence opposition candidates? He smiled, swirled his wine glass, took a sniff, and pronounced that good deeds follow good words. A convincing argument but pure rubbish coming from a public relations flack for a totalitarian government.

'Your job,' I said, 'is to sell a contrived image for a military regime that seized power, closed Parliament, jails journalists and rules by decree. My job is to train journalists to look behind your clever words to investigate whether the facts match the promises. The only difference is you are paid handsomely for spinning it but my reporters and students can be jailed for exposing it.'

After 20 years, it is sad to watch a tiny nation blessed with beauty, abundance and a global reputation as 'paradise' devolve into paralysis and dysfunction. It could turn tragic if it drags its tiny neighbours down with it. In a syndicated 1996 Los Angeles Times column (Hooper, 1996) I cautioned,

We must remain engaged in the Pacific and in East Asia, for we cannot rely on spy satellites and military power alone to promote our interests. The goodwill and constructive engagement we are thoughtlessly abandoning will not be rebuilt overnight or at some future time of crisis.

Small, poor, strategically 'irrelevant' countries like Fiji — or Afghanistanhad become redundant after the Cold War. 'In a climate of economic restructuring,' wrote Solomon Islander Ashley Wickham, 'our former colonial powers see us with cold eyes and new "friends" see us with calculating eyes.' A decade later, one new 'friend' caught everyone by surprise.

By the time Bainimarama staged the 2006 coup, China occupied a gleaming new embassy at Suva Point and had dramatically increased aid to 
Fiji. China's Vice President Xi Jinping dropped in unannounced to meet Bainimarama just months before Fiji's Constitution was abrogated in 2009, followed by China's top legislator, Wu Bannguo in 2012 to sign off on $\$ 200$ million in soft loans. Prominent Chinese development projects now line the Queens Highway into Suva and People's Liberation Army troops were deployed to restore Prince Albert Park and Thurston Gardens and tidy up Fiji's capital city. In return, the Bainimarama government praised Beijing's policies on Tibet and Taiwan, a token down payment on the 'checkbook diplomacy' Fiji's estranged traditional partners, Australia and New Zealand, most fear.

Chinese 'public diplomacy' is now ubiquitous and mass media and higher education will follow. In 2011, top Fiji TV reporters were flown to Beijing for 'briefings' by Chinese government officials and lavishly entertained in Shanghai and other Chinese cities (Hooper, 2011). They saw through the sham but enjoyed the attention. One said he wasn't worried Fiji would turn into China, rather Burma or even Zimbabwe. He has a backup plan to emigrate, joining an exodus of top professionals that include former top Fiji TV news editor Merana Kitione and former Fiji Broadcasting Corporation chief executive officer Francis Herman, who now work in Vanuatu.

In the background, a global realignment of hegemony is taking place in the Western Pacific for the first time since Imperial Japan surrendered in 1945. Strategic diplomacy and trade competition, naval deployments and the potential for military confrontation will play out over the next decade. In February 2012 - the same month I observed a Chinese satellite communications ship docked at Suva wharf-Russian Foreign Minister Sergei Lavrov arrived to offer aid and educational assistance, the first visit by a Russian Foreign Minister since the Soviet Union established diplomatic relations in 1974. 'The Pacific is the priority of foreign policy for the Russian Federation,' Lavrov told a press conference following his meeting with Bainimarama (Republic of Fiji Ministry of Foreign Affairs, 2012). Fears that Russia was lobbying for recognition of disputed territories South Ossetia and Abkhazia wrested from Georgia in the 2008 war proved unfounded-for now. But larger geopolitical issues are at stake and unprecedented visits by a Russian foreign minister and top Chinese political leaders signal the first serious challenge to Western supremacy in the Pacific since Japanese troops seized Guadalcanal in May 1942. Such diplomatic machinations are only the opening salvo. The Russians and Chinese have been carefully reading Japan's pre-WWII playbook. 
Having just spent two years strengthening journalism education at Fiji's pre-eminent university and its national television service, I found Russian Foreign Minister Lavrov's top priority - educational assistance and scholarships at Russian universities - doubly ironic. I had lobbied the US State Department repeatedly to place a single Fulbright Scholar at the University of the South Pacific, without success. With Fiji's barking dogs of journalism silenced or in exile, what will Russian and Chinese academics teach the next generation of reporters? What dogs will bark when the poverty rate in Fiji grows from 25 percent to 45 percent despite billions invested by government, NGOs, and the international aid industry? What dogs will bark when Fiji's national retirement fund is looted, or farmers are evicted from land they have tilled for generations, or the fish in Namosi River are poisoned by mining wastes and sicken villagers downstream? What dogs will bark when rising sea levels threaten coastal taro farmers and force entire villages into poverty? What dogs will bark when the children can no longer read or write?

It has been 20 years since the US Embassy first invited me to Fiji to address the PINA and serve as a Fulbright Scholar to the University of the South Pacific. By 1996 the US Embassy had been virtually abandoned except for a lonely receptionist who apologised when she interrupted my brief appointment with the ambassador. Today, a gleaming new US Embassy overlooks Suva from Tamavua Heights and diplomatic attention is belatedly returning to the Pacific. But as US Ambassador D. Brent Hardt (Guyana) cautioned me on my return to the US, America is redeploying to the Asia-Pacific, but 'it takes time to turn the carrier'. I can only suggest we deploy that carrier at flank speed or accept the consequences.

\section{Note}

1. An archive of Pacific Journalism Online stories about the 2000 Speight coup in Fiji is maintained at the University of Technology, Sydney (see www.pmc.aut. ac.nz/articles/archive-internet-coup-fiji-2000 )

\section{References}

Delaivoni, C. (2008, September 11). USP employees walk off their job, The Fiji Sun, Retrieved on January 15, 2013, from www.fijisun.com.fj/2008/09/11/uspemployees-walk-of-their-job/

External exams scrapped to reduce dropouts: Bole (2010, June 30). Fiji Sun. Retrieved on January 15, 2013, from www.fijitimes.com/story.aspx?id=213349 
Fiji Times found guilty (2012, October 2). The Fiji Times Online. Retrieved on January 15, 2013, from www.fijitimes.com/story.aspx?id=213349

Fiji's repressive media decree takes effect (2010, June 28). Committee to Project Journalists. Retrieved on January 15, 2013, from www.cpj.org/2010/06/fijisrepressive-media-decree-takes-effect.php

Hooper, R. A. (2012, June 16), Personal correspondence with USP journalism student. Hooper, R. A. (2011, March 4). Fiji TV newsroom, class discussion with Fiji TV reporters.

Hooper, R. A. (1998). Challenges of sustainable broadcast training in contemporary Pacific, AsiaPacific MediaEducator, July-December, 5, 4-22.

Hooper, R. A. (1996, December 26), America's retreat from the New Pacific, The Los Angeles Times, p. B7.

Kafka, F. (1998). The trial. (B. Mitchell, Trans.). New York, NY: Schocken Books. (Original work published 1925)

Marcel, G. (1998). Gabriel Marcel's perspectives on the broken world: The broken world, a four-act play, followed by concrete approaches to investigating the ontological mystery. (Katharine Rose Hanley, Trans.). Milwaukee: Marquette University Press. (Original work published 1933)

Robie, D. (2004). Mekim Nius: South Pacific media, politics and education. Suva: University of the South Pacific Book Centre.

Sharma, S. (2010), Bangladesh Mum. YouTube. Retrieved on January 15, 2013, from www.youtube.com/watch?v=PUPdqy0PD I

Strike illegal: USP (2008, September 11). The Fiji Times Online. Retrieved on January 15, 2013, from www.fijitimes.com/story.aspx?id=100320

Stewart, P. (1966), Ginzburg v. United States, 383 U.S. 463

Swami, N. (2012, October 2). Fiji Times Ltd found guilty, The Fiji Times Online, Retrieved on January 15, 2013, from www.fijitimes.com/story.aspx?id=213349

The Republic of Fiji Ministry of Foreign Affairs (2012, February 4). Russian Foreign Minister visits Fiji [Media release]. Retrieved on January 15, 2013, from www. foreignaffairs.gov.fj/media-resources/media-release/166-russian-foreign-ministervisits-fiji

Professor Robert A. Hooper is an attorney and award-winning producer for the Public Broadcasting Service (PBS), and has served as a Fulbright Senior Scholar and Eisenhower Fellow to Asian and Pacific Island nations. A member of the faculty of the University of California, San Diego, he teaches courses on media, democracy and terrorism at the Graduate School of International Relations and Pacific Studies.

pjreview@aut.ac.nz 